DOI: 10.46340/eppd.2020.7.6.10

\author{
Marta Shturma \\ ORCID ID: https://orcid.org/0000-0002-8129-5917 \\ Ivan Franko National University of Lviv, Ukraine
}

\title{
THE TRANSATLANTIC DIMENSION OF DENMARK'S SECURITY POLICY AT THE BEGINNING OF THE 21ST CENTURY
}

\author{
Марта Штурма

\section{ТРАНСАТЛАНТИЧНИЙ ВИМІР У ПОЛІТИЦІ БЕЗПЕКИ ДАНІЇ НА ПОЧАТКУ ХХІ СТ.}

Львівський національний університет імені Івана Франка, Україна

\begin{abstract}
The article focuses on the transformation of Denmark's approaches to the implementation of its security priorities at the beginning of the XXI century. The study identifies the reasons for Denmark's renunciation of its "restrained" position in NATO and explains the transition to a proactive position on peace settlements in different parts of the world. It emphasizes the importance of liberal democratic values in Danish military activism. The article examines the Denmark's contribution to military operations in Afghanistan, Iraq and Libya. The priority of Denmark's cooperation with the United States is substantiated as cooperation with a key security partner. The study stresses that the predominance of Atlanticism and NATO active support were the reasons for Denmark's self-exclusion from the EU's Common Security and Defence Policy and for its ambivalent position towards security initiatives at the regional level. It also underscores the relevance of the Danish experience in reforming the armed forces and the transition to crisis management as an effective way to manage new security challenges.
\end{abstract}

Keywords: Denmark, USA, NATO, foreign policy, security policy, Atlanticism, activism, interventionism, liberal values.

Постановка проблеми. Королівству Данія, після завершення міжблокового протистояння, завдяки ефективній зовнішньополітичній діяльності й послідовній позиції при вирішенні багатьох питань безпекового характеру, вдалося істотно посилити власний вплив у міжнародному середовищі. Взаємодія цієї країни з іншими учасниками міжнародних відносин у сфері безпеки зазнала докорінної трансформації й відбувається сьогодні за зразком могутніх та впливових міжнародних акторів. Водночас, готовність країни до глибшого залучення в інституційні форми гарантування безпеки, що розвиваються у Північній Свропі чи в рамках $\mathrm{CC}$, безпосередньо залежить від стану трансатлантичних відносин (НАТО) та характеру взаємодії зі США, як пріоритетним партнерством. Тому цілісне розуміння сучасних зовнішньополітичних орієнтацій та безпекової стратегії Данії $\epsilon$ актуальним з погляду української теорії та практики, адже відкриває перспективи для (пере)осмислення і належного оновлення підходів України до питань безпекового характеру, зокрема, в процесі взаємодії з НАТО.

Аналіз останніх досліджень і публікацій. Питання зовнішньої та безпекової політики державних акторів $€$ достатньо опрацьованим у науковій літературі. 3 огляду на значний теоретичний та прикладний інтерес, різні аспекти реалізації безпекової політики Королівства Данія також широко представлені в сучасному політологічному дискурсі (А. Вівель, К. Крістенсен, К. Ларсен, Н. Петерсен, С. Райнінг). Водночас слід констатувати брак цілісних досліджень безпекової політики Королівства Данія, що брали б до уваги ефективність трансатлантичного зв'язку для їі забезпечення з одного боку, й зростання значення колективного опрацювання безпекових викликів і загроз у сучасному світі, -3 іншого.

Метою статті є розгляд трансатлантичного вектора безпекової політики Королівства Данії на початку XXI ст., як основи для реалізації національних пріоритетів країни у безпековій сфері. 
Завданнями статті є окреслити трансформацію данських підходів щодо гарантування національної і міжнародної безпеки й висвітлити роль трансатлантичних відносин у сучасній безпековій політиці цієї країни. Досягнення мети й реалізація завдань статті досягаються шляхом застосування системного підходу й використання методів аналізу, синтезу та порівняння. Епістемологічною основою дослідження є засади політичного реалізму та неореалізму.

Виклад основного матеріалу. У період міжблокового протистояння Данія була беззаперечною частиною колективного Заходу, а з військового погляду, - інтегрованою у німецьку частину командування НАТО «БАЛТАП». Так само, iї розглядали як складову «Нордичного балансу», що формувався на заході по осі Норвегія-НАТО, а на сході включав Фінляндію. Північноатлантичний альянс займав домінуючу позицію, слугуючи єднальною ланкою між США та Західною Європою. Ці умови дали змогу Данії відігравати роль «стриманого» члена НАТО, й мати серйозні застереження щодо політики альянсу відносно Радянського Союзу у 1980-х рр. Такий підхід Данії часто визначали як «політику застережень»- footnoting ${ }^{1}$. У цей час Данія намагалася також здійснювати власну політику розрядки, відстоюючи ті цінності, які могли бути спільними як для Заходу, так і для Сходу, знижуючи, таким чином, рівень ідеологічного протистояння.

Після холодної війни геополітична позиція Данії істотно змінилися й країна тривалий час розвивалася у щораз безпечнішому регіональному середовищі. Вступ Польщі (1999 р.), а згодом і країн Балтії (2004 р.) у НАТО, сприяв істотному покращенню безпекового середовища Данії, порівняно із ситуацією, яка існувала раніше ${ }^{2}$. Зникнення прямих загроз для Данії стало сприятливим чинником для перебудови данських збройних сил й дало змогу цій країні використовувати власні війська $з$ метою реалізації інтересів провідних держав-членів Північноатлантичного альянсу ${ }^{3}$. Данія почала позиціонувати себе як стратегічного гравця ${ }^{4}$, а багато країн-членів НАТО стали розглядати іiі як «бездоганного союзника» 5 .

Активізація данської політики щодо забезпечення миру у постбіполярний період була відповіддю на збільшення світового попиту на міжнародні військові операції. Інша причина успіху Данії у цій площині полягала у готовності данського політикуму скеровувати власні війська для участі у міжнародних операціях під егідою НАТО. Зокрема, першим помітним кроком стало надсилання данських військових для місій Північноатлантичного Альянсу на Балканах 6 .

На зламі XX й XXI століть кількість та складність миротворчих операцій суттєво зросла. Вони більше не зводилися лише до функції захисту цивільного населення в умовах громадянського протистояння чи збройних конфліктів, а й набували щораз виразнішого проактивного наступального характеру, спрямовуючись на відстоювання гуманітарних цінностей чи прав людини. Внесок НАТО, ЄС або ad-hock коаліцій «доброї волі» у забезпечення міжнародної стабільності ставав усе істотнішим, збільшуючи попит на країни, готові власними військовими засобами долучатися до операцій чи легітимізувати їх за допомогою своєї безпосередньої участі. У цьому контексті Данія надавала відносно високу щодо власного розміру та чисельності населення частку військових для реалізації подібних міжнародних місій, демонструючи, тим самим, готовність до дій у зонах підвищеного ризику як, наприклад, Афганістан ${ }^{7}$.

3 іншого боку, Данія послідовно обстоювала ідею багатосторонньої оборони, свідченням чого стала реакція уряду цієї країни на терористичні акти 11 вересня 2001 р. у США, коли Копенгаген

\footnotetext{
${ }^{1}$ Heurlin, B. (1996). Denmark: a new activism in foreign and security policy. in Ch. Hill (Ed.), The Actors in Europe's Foreign Policy. London: Routledge, 174.

${ }^{2}$ Hækkerup, H. (2002) På Skansen. Denmark: Lindhardt and Ringhof, 53-57.

${ }^{3}$ Heurlin, B. (2004). Riget, magten og militceret. Dansk forsvars- og sikkerhedspolitik under forsvarskommissionerne af 1988 og af 1997. Aarhus: Aarhus Universitetsforlag, 254-261.

${ }^{4}$ Rynning, S. (2003). Denmark as a strategic actor? Danish Security Policy after 11 September. in P. Carlsen and H. Mouritzen (eds), Danish Foreign Policy Yearbook 2003. Copenhagen: DIIS, 23-46.

${ }^{5}$ Ringsmose, J. Rynning, S. (2008). The Impeccable Ally? Denmark, NATO, and the Uncertain Future of Top Tier Membership. in N. Hvidt and H. Mouritzen (eds), Danish Foreign Policy Yearbook 2008. Copenhagen: Danish Institute for International Studies, 55-84.

${ }^{6}$ Ringsmose, J. Rynning, S. (2008). The Impeccable Ally? Denmark, NATO, and the Uncertain Future of Top Tier Membership. in N. Hvidt and H. Mouritzen (eds), Danish Foreign Policy Yearbook 2008. Copenhagen: Danish Institute for International Studies, 61.

${ }^{7}$ Ringsmose, J. Rynning, S. (2008). The Impeccable Ally? Denmark, NATO, and the Uncertain Future of Top Tier Membership. in N. Hvidt and H. Mouritzen (eds), Danish Foreign Policy Yearbook 2008. Copenhagen: Danish Institute for International Studies, 62.
} 
відразу підтримав застосування ст. 5 НАТОํ․ Отож, первинною реакцією Данії була солідарність у рамках багатосторонніх інституцій, що відповідало міжнародній практиці 1990-х рр.

Однак змінилась позиція самих США, які, готуючи відповідь на терористичний напад, мало зважали на безпекові союзи. Новий американський підхід ставив під сумнів традиційні багатосторонні стратегії, яких дотримувалися малі держави, змушуючи їх до вибору: або залишатися й надалі відданими широкому мультилатераліму, або ставати частиною вузької коаліції, очолюваної США. Таким чином, данцям слід було визначитися щодо власної участі у потенційній військовій операції в Афганістані.

Ці події співпали із парламентськими виборами у Данії, на яких переконливу перемогу здобули ліберали. Вони отримали змогу самостійно, без коаліції, сформувати новий уряд, який 13 грудня 2001 р. звернувся до парламенту з проханням схвалити участь Данії у міжнародній коаліції під керівництвом США, створеній на основі резолюції ООН, й задекларувати готовність до істотного внеску країни в майбутні військові діїㄹ. Водночас, опозиція намагалися відстояти традиційний для Данії мультилатералізм і обстоювала необхідність здійснення операції під егідою ООН, а не за безпосереднього лідерства США. У підсумку парламент підтримав пропозицію урядуㄹ․ Данія долучилася до військових акцій в Афганістані, розгорнувши там спеціальні наземні сили та надавши літаки $\Phi-16$, які були розташовані на військовій базі в Киргизстані ${ }^{4}$.

Таким чином, на початку XXI ст. виникло сприятливе середовище для розвитку данського активізму ${ }^{5} .3$ перспектив Данії, відбулася відмова від реалізму невеликої держави, що полягав на самоусуненні. Натомість було адаптовано «звичайний» реалізм, що передбачав безпосередню участь у міжнародному житті, коли цього вимагають нагальні обставини ${ }^{6}$.

Особливу роль у цих процесах відіграв данський прем'єр-міністр А. Расмуссен, котрий надавав зовнішньополітичного активізму більш чіткого ідеологічного забарвлення, особливо акцентуючи на спільності цінностей Данії та США. Забезпечення миру саме по собі, на переконання А. Расмуссена, не мало особливого значення. Важливими для нього були цінності, які гарантують мир, серед яких найважливішим було звільнити людей від авторитарних правителів, створюючи для них можливість для самостійного вибору. Зокрема, це був один з аргументів при обгрунтуванні військового втручання в Ірак ${ }^{7}$.

США мали незначні очікування щодо внеску Данії в афганську та іракську кампанії, що пояснювалося двома чинниками - розміром цієї країни та її попередньою політикою. Адже у період холодної війни Данія розглядала власне членство в НАТО лише крізь призму американських безпекових гарантій i не вважала власну армію спроможною забезпечити оборону країни. Результатом цього стало виконання Данією власних зобов'язань на мінімальному рівні. Ситуація поступова почала змінюватись у 1990-х рр., коли Данія надала як політичну, так і військову підтримку США у Перській затоці та на Балканах, однак очікування американців щодо військового внеску королівства у контексті терористичних атак 11 вересня 2001 р. були все ж невисокими ${ }^{8}$. Тому збройний внесок Данії в Афганістані став приємним сюрпризом для американців.

Нормативна основа для здійснення таких операцій засвідчила сумісність американських i данських цінностей, що було менш помітним у період холодної війни. Для Данії завжди була властива атлантична традиція. Незважаючи на політику застережень чи «латентну» нейтральність в підходах

\footnotetext{
${ }^{1}$ Rynning, S. (2003). Denmark as a strategic actor? Danish Security Policy after 11 September. in P. Carlsen and H. Mouritzen (eds), Danish Foreign Policy Yearbook 2003. Copenhagen: DIIS, 24.

${ }^{2}$ Petersen, N. (2006). Europaeisk Og Globalt engagement 1973-2006, Dansk Udenrigspolitiks Historie. Bind 6. København: Gyldendal, 608-609.

${ }^{3}$ Pedersen, R. (2012). Danish foreign policy activism: Differences in kind or degree? Cooperation and Conflict, 47 (3), 339.

${ }^{4}$ Petersson, M., Saxi, H. (2013). Shifted Roles: Explaining Danish and Norwegian Alliance Strategy 1949-2009. Journal of Strategic Studies, 36 (6), 772.

${ }^{5}$ Rasmussen, A. F. (2003). Visioner for Danmarks aktive Europapolitik. Statsminister Anders Fogh Rasmussens tale på Københavns Universitet den 23 September $2003<\mathrm{http}$ ://www.stm.dk/_p_7451.html> (2020, October, 10).

${ }^{6}$ Petersen, N. (2006). Efter Muhammed: Handlerummet for den borgerlige udenrigspolitik. Militcert Tidsskrift, 135 (2), 183.

${ }^{7}$ Rasmussen, A. F. (2003). Address by Prime Minister of Denmark Anders Fogh Rasmussen. The Woodrow Wilson Center, Washington, May 9, 2003. <http://www.stm.dk/_p_7430.html> (2020, August, 23).

${ }^{8}$ Ringsmose, J., Jakobsen, P. (2015). Size and reputation - why the USA has valued its 'special relationships' with Denmark and the UK differently since 9/11? Journal of Transatlantic Studies, 13 (2), 143.
} 
до питань оборони, Данія була міцно інкорпорована у Північноатлантичний альянс. Про це свідчили, зокрема, iї згода на розміщення американських військ у Гренландії чи відсутність відкритої критики на адресу США. Окрім того, обидві країни об'єднували класичні ліберальні цінності як права людини, ринкова економіка й ліберальна демократія. На цьому почали виразно наголошувати після завершення холодної війни, з огляду на поступову втрату значення нордичної безпекової складової.

Активізм став частиною данської політики та данської стратегічної культури. Він опирається на ліберальні цінності та відсутність значних ідеологічних розбіжностей щодо цього у політичних сил країни. Важливу роль продовжувало відігравати поєднання егалітаристських та ліберальних цінностей. Водночас, важливе місце продовжувала займати підтримка країн, що розвиваються. Слід нагадати, що військові аспекти були інтегровані у данську політику розвитку. Якщо у період холодної війни ця політика, як частина зусиль Данії щодо забезпечення миру, протиставлялася мілітаристським за своїм характером політикам США та СРСР, то сьогодні вона спрямована на надання країнам третього світу відповідних ресурсів з метою забезпечення стабільності і безпеки. Тому, наприклад, Данія підтримала розбудову миротворчих сил ПАР у 1997 р¹.

Утім справжнє протистояння між традиційним інтернаціоналізмом i наступальним міжнародним активізмом стало помітним у 2002 р., коли почалися обговорення інтервенції США в Ірак. Якщо втручання в Афганістан підтримувала абсолютна більшість, то у випадку Іраку - йшлося про незначну перевагу. Одним з основних контраргументів була відсутність мандату $\mathrm{OOH}^{2}$.

Тим не менше, користь для Данії полягала в істотному покращенні іміджу країни у Вашингтоні, полегшенню доступу до американського політикуму на усіх рівнях та отриманні матеріальної й політичної підтримки ${ }^{3}$. Водночас, королівство отримало також кращий доступ до американських інституцій. Це, заразом, істотно поліпшило позиції Данії на міжнародній арені й створило більш сприятливі умови для ухвалення рішень зовнішньополітичного і військового характеру. Окремо слід вказати також на можливість полегшення доступу Данії до новітніх військових технологій ${ }^{4}$. Завдяки власній активній міжнародній політиці, Данії вдалося тісніше заангажувати США у проблематику Арктики i, таким чином, посилити власні позиції у регіоні відносно Росії.

Часто вказують, що НАТО перетворилася на дворівневий альянс. У той час, як частина державчленів перебрала на себе основний тягар колективної оборони, інша перетворилася на фрі-райдерів, що користуються безпековою парасолькою НАТО. Навіть йдеться про поділ країн на «команду А», до якої належать члени, що роблять непропорційно великий щодо власного потенціалу внесок у функціонування альянсу, та «команду В», що складається, в основному, зі споживачів безпеки .

У цьому контексті Данія належить до «команди А» чи, іншими словами, стала частиною «вищої ліги НАТО». Цьому сприяли водночас два чинники: докорінна перебудова данських збройних сил та політична готовність країни до їхнього застосування під час міжнародних операцій на Балканах, а, що важливіше, - в Афганістані

Помітний внесок Данії у міжнародну місію під егідою НАТО в Афганістані остаточно дав змогу вважати королівство частиною «команди А» в альянсі. Менш однозначним за наслідками стало рішення взяти участь в інтервенції в Ірак у рамках американської коаліції у 2003-2007 pp. 3 одного боку, вона ще більше зблизила Данію зі США, а з іншого - відбулась за рамками НАТО і не мала підтримки з боку значної кількості членів альянсу, насамперед Франції та Німеччини. Останні жорстко критикували США та висловлювали розчарування 3 приводу участі Данії у цій контроверсійній з погляду міжнародного права американській ініціативі.

Утім дискусія мала більш фундаментальний характер й стосувалася зміцнення тренду активізму у зовнішній політиці, адже участь в американській коаліції була передумовою для міжнародного

\footnotetext{
${ }^{1}$ Wivel, A. (2013). From Peacemaker to Warmonger? - Explaining Denmark's Great Power Politics. Swiss Political Science Review, 19 (3), 316. <https://onlinelibrary.wiley.com/doi/pdf/10.1111/spsr.12043> (2020, January, 17).

${ }^{2}$ Pedersen, R. (2012). Danish foreign policy activism: Differences in kind or degree? Cooperation and Conflict, 47 (3), 340.

${ }^{3}$ Ringsmose, J., Jakobsen, P. (2015). Size and reputation - why the USA has valued its 'special relationships' with Denmark and the UK differently since 9/11? Journal of Transatlantic Studies, 13 (2), 144.

${ }^{4}$ Ringsmose, J., Jakobsen, P. (2015). Size and reputation - why the USA has valued its 'special relationships' with Denmark and the UK differently since 9/11? Journal of Transatlantic Studies, 13 (2), 145.

${ }^{5}$ Rynning, S., Ringsmose, J. (2008). The impeccable ally? Denmark, NATO, and the uncertain future of top tier membership. Danish Foreign Policy Yearbook 2008. Copenhagen: Danish Institute for International Studies, 57.

${ }^{6}$ Там само.
} 
посилення позицій Данії та збільшення простору для дій на міжнародній арені. Рішення данців стати на бік США стало свідченням ще більш наступального за характером зовнішньополітичного активізму з огляду на участь у тимчасових коаліціях за межами багатосторонніх інституцій. Водночас, при обгрунтуванні таких кроків активно використовували проблематику цінностей, вказуючи на необхідність боротьби демократій з диктатурами ${ }^{1}$.

Міжнародний активізм вирізняється 3-поміж попередніх різновидів зовнішньополітичної поведінки Данії, адже у площині захисту цінностей йшлося не про право захищати демократії, а саме про обов'язок так чинити. Наголошували, що Данія повинна позбутися комплексу малої держави, відмовитися від спроб ізоляції чи нейтралітету, та стати частиною широкого глобального консенсусу, який надає країні нові можливості для міжнародного впливу, зокрема завдяки союзу зі США. Участь у гнучких коаліціях, яких об'єднують спільні цілі та цінності, покликана сприяти реалізації цієї мети.

Окрім ідеологічних аргументів, існували також міркування Realpolitik. Партнерство зі США розглядали як можливість для Данії перетворитися з малої у середню потугу, й не використовувати лише активну адаптацію.

Класичним прикладом мілітарного активізму стало рішення скерувати данських військових для участі у наземних операціях в Іраку (2003р.). Це рішення було підтримане більшістю парламентарів країни ${ }^{2}$. Данія приєдналася до американської коаліції та надала для ії потреб як своїх військових, так i власні кораблі. Збройні сили Данії були одночасно розташовані в Афганістані, Косово та Іраку, що було своєрідним викликом для країни у безпековій сфері ${ }^{3}$. Участь у цих операціях супроводжувалась одночасною перебудовою збройних сил Данії, що мало покращити можливості країни з ефективнішої участі у подібних заходах, здійснюваних як під егідою НАТО, так і в складі коаліцій на чолі зі США.

Збройні сили Данії відмовилися від озброєння та військового спорядження, яке було непридатним для ведення асиметричних війн, як підводні човни чи сухопутні системи протиповітряної оборони. Інтенсивне залучення у міжнародні військові операції було покликане зміцнити позиції Данії на міжнародній арені та перетворити військові засоби в інструмент зовнішньої політики у відносинах з іншими країнами, насамперед зі США

Ще помітнішим прикладом мілітарного активізму стало розгортання у 2006 . данських військових в афганській провінції Хелманд, де їм довелося вести інтенсивні бойові дії. Данське командування розглядало цей крок як можливість продемонструвати внесок Данії у стабілізацію Афганістану, показати данському політикуму важливість збройних сил як інструменту зовнішньої політики та, водночас, засвідчити рівень власної бойової підготовки ${ }^{5}$. Ці кроки збільшили заразом помітність країни серед членів НАТО. Данські військові також отримали змогу набути безпосередній бойовий досвід, однак не обійшлося й без втрат особового складу: зокрема, у 2009 р. загинуло приблизно 30 данських солдатів.

Підтримка афганської місії серед населення Данії була досить високою - 40-50\%, незважаючи на наявність людських втрат. При цьому, рівень суспільної підтримки цієї операції був одним за найвищих серед країн, які взяли в ній участь, i, де-факто, був тотожній цьому показнику в США ${ }^{6}$.

Участь у міжнародних військових місіях принесла значні політичні дивіденди для Данії. Зокрема, уряд країни зміг налагодити конструктивні відносини зі США, що вирізнило Данію 3-поміж інших союзників по НАТО. А. Расмуссен, як прем'єр-міністр Данії, сім разів відвідував президента Дж. Буша-молодшого, а данські дипломати отримали привілейований доступ та вплив у Вашингтоні.

\footnotetext{
${ }^{1}$ Pedersen, R. (2012). Danish foreign policy activism: Differences in kind or degree? Cooperation and Conflict, 47 (3), 340 .

${ }^{2}$ Kristensen, K. S., Larsen, K. K. (2017). Denmark's Fight Against Irrelevance, or the Alliance Politics of 'Punching Above Your Weight' in M. Wesley (Ed.), Global Allies. Comparing US Alliances in the 21st Century. Canberra: ANU Press, 65.

${ }^{3}$ Petersson, M., Saxi, H. (2013). Shifted Roles: Explaining Danish and Norwegian Alliance Strategy 1949-2009. Journal of Strategic Studies, 36 (6), 773.

${ }^{4}$ Szymański, P. (2018). Overstretched? Denmark's security policy and armed forces in light of the new Defence Agreement. OSW Commentary, 266. Warsaw: Centre for Eastern Studies, 2.

$<$ https://www.academia.edu/36561702/Piotr_Szyma\%C5\%84ski_Overstretched_Denmark_s_security_policy_and_ar med_forces_in_light_of_the_new_Defence_Agreement_OSW_Commentary_No_266_20_04_2018> (2019, May, 05).

${ }^{5}$ Vedby, M. (2011). Rasmussen, Den Gode Krig. Copenhagen: Gyldendal, 24.

${ }^{6}$ Jakobsen, P. V., Ringsmose J. (2014). In Denmark, Afghanistan is Worth Dying for: How Public Support for the War was Maintained in the Face of Mounting Casualties and Elusive Success. Cooperation and Conflict, 50, 2, 211-227. DOI: https://doi.org/10.1177/0010836714545688.
} 
Значна кількість таких двосторонніх візитів є безпрецедентним випадком для малої країни у ії відносинах зі США ${ }^{1}$. Без цього, досить малоймовірним $\epsilon$ те, що станом на 2012 р. ключові посади одночасно посіли б два данці- А. Расмуссен, як Генеральний Секретар та К. Бартелс, як Голова військового комітету Північноатлантичного альянсу².

Необхідно відзначити, що вплив Данії на свого ключового партнера радше не був значним. У будь-якому випадку, партнерство зі США було важливим інформаційним приводом та збільшувало статус країни у відносинах з іiї європейськими партнерами ${ }^{3}$. При цьому, слід мати на увазі, що серед партнерів по НАТО не лише Данія прагнула мати статус спеціального партнера у відносинах зі США. Тут їй доводилося конкурувати з іншими країнами як Велика Британія, Польща чи Нідерланди. Тому цілком передбачуваним став крок данського уряду щодо участі країни у військовій операції НАТО у Лівії. Усі політичні сили у парламенті країни, навіть радикальні соціалісти, підтримали уряд.

Данія не висунула жодних вимог щодо можливих обмежень у використанні власної авіації під час цієї місії. Загалом, у Лівії НАТО здійснила понад 9,7 тис. бойових вильотів і знищила приблизно 6 тис. військових цілей. При цьому, данські винищувачі Ф-16 виконали понад 600 бойових вильотів ${ }^{4}$. 3 огляду на їхній внесок, командувач операції навіть назвав данські винищувачі «суперзірками кампанії» ${ }^{5}$. А за словами тодішнього держсекретаря США Р. Гейтса, під час лівійської операції Норвегія та Данія спільно забезпечили $12 \%$ бойових вильотів і вразили понад третину цілей. На його переконання, обидві країни, маючи обмежені ресурси, змогли здійснити успішну підготовку та надати військове спорядження, необхідні задля належного забезпечення їхнього військового внеску ${ }^{6}$. Він відзначив Данію разом з Норвегією, Бельгією та Канадою, як приклади союзників, гідні для наслідування з боку інших партнерів по альянсу.

Зауважимо, що крім авіації, Данія надала також значну кількість військового спорядження, що виявилося дуже важливим для успішного здійснення операції. Внесок Данії якісно і кількісно перевищив ії очікуваний потенціал ${ }^{7}$. Лівійська кампанія ще більше посилила позиції Копенгагена у відносинах із Вашингтоном, а США знову наводили Данію як приклад іншим європейським союзникам.

Показовими у цьому контексті стали також події вересня 2014 р., коли Данія заявила про готовність надати власні винищувачі для боротьби з Ісламською державою. У підсумку, це рішення отримало підтримку $90 \%$ депутатів ${ }^{8}$.

Така майже автоматична відповідь на ініціативи США й внутрішній консенсус у Данії майже нікого не здивував. Роком раніше, під час візиту Б. Обами до Швеції, де були присутні також очільники Фінляндії, Норвегії, Ісландії, прем’єр-міністр Данії заявила про готовність підтримати США у військовій боротьбі зі сирійським режимом, хоча Вашингтон ще не озвучував жодних планів щодо цього. Така позиція Данії докорінно відрізнялася від підходів інших чотирьох скандинавських країн, які відмовлялися бути втягнутими у будь-який тип інтервенції9. При цьому, публічні дискусії

\footnotetext{
${ }^{1}$ Kristensen, K. S., Larsen, K. K. (2017). Denmark's Fight Against Irrelevance, or the Alliance Politics of 'Punching Above Your Weight' in M. Wesley (Ed.), Global Allies. Comparing US Alliances in the 21st Century. Canberra: ANU Press, 72.

${ }^{2}$ Rynning, S. (2013). Denmark. in H. Biehl, B. Giegerich\&A. Jonas (eds). Strategic Cultures in Europe. Security and Defence Policies Across the Continent. Wiesbaden: Springer Fachmedien, 91.

${ }^{3}$ Mouritzen, H. (2006). Atlantic reform. A Euro-atlantic and a Danish perspective. Danish Institute for International Studies REPORT, 3, 31.

${ }^{4}$ Rynning, S. (2013). Denmark. in H. Biehl, B. Giegerich\&A. Jonas (eds). Strategic Cultures in Europe. Security and Defence Policies Across the Continent. Wiesbaden: Springer Fachmedien, 93.

${ }^{5}$ Møller, K. J., Jakobsen, P. V. (2012). Good News: Libya and the Danish way of War. in N. Hvidt and H. Mouritzen (eds), Danish Foreign Policy Yearbook 2012. Copenhagen: Danish Institute for International Studies, 106-130.

${ }^{6}$ Gates, R. (2011). Text of Speech by Robert Gates on the Future of NATO. Atlanticcouncil

$<$ https://www.atlanticcouncil.org/blogs/natosource/text-of-speech-by-robert-gates-on-the-future-of-nato/>. (2020, May, 12).

${ }^{7}$ Mueller, K. P. (2015). Precision and Purpose: Airpower in the Libyan Civil War. Santa Monica: RAND Corp.

${ }^{8}$ Kristensen, K. S., Larsen, K. K. (2017). Denmark's Fight Against Irrelevance, or the Alliance Politics of 'Punching Above Your Weight' in M. Wesley (Ed.), Global Allies. Comparing US Alliances in the 21st Century. Canberra: ANU Press, 68.

${ }^{9}$ Kristensen, K. S., Larsen, K. K. (2017). Denmark's Fight Against Irrelevance, or the Alliance Politics of 'Punching Above Your Weight' in M. Wesley (Ed.), Global Allies. Comparing US Alliances in the 21st Century. Canberra: ANU Press, 68.
} 
в Данії не стосувалися питання, чи надсилати власну авіацію у Сирію, а того, коли це зробити 3 найбільшою ефективністю. Отож, безумовна підтримка будь-якої потенційної акції США, швидкість ухвалення рішення, консенсус 3 цього приводу у середовищі данського політикуму та відсутність протестів з боку населення, вирізняє Данію 3-поміж решти країн Європи.

Атлантичний характер безпекової та оборонної політики Данії дав змогу окремим аналітикам стверджувати про «суператлантизм» ${ }^{1}$ цієї країни чи характеризувати ії як «бездоганного союзника» по $\mathrm{HATO}^{2}$. Серед данських політиків домінує переконання, що вибір на користь атлантичного напряму був вдалим, адже збільшив вплив країни як в НАТО, так і у США³.

Сьогодні США $є$ не лише основними постачальниками озброєнь і військового оснащення, вони також виступають як основний гарант для Данії із забезпечення свободи морського судноплавства та торгівлі. Цей чинник $є$ особливо важливим з огляду на те, що захист морських торговельних шляхів має для данців особливе значення, адже від цього залежить добробут населення країни.

Таким чином, застосування військової сили стало невід’ємною частиною данської зовнішньої політики. 31990 р. по 2017 р. Данія взяла участь у 68-и міжнародних військових операціях під егідою НАТО, ООН, ОБСЕ чи у рамках міжнародних коаліцій. Для порівняння, з 1945 р. по 1989 р. Данія долучилась лише до 13 міжнародних військових операцій і всі вони здійснювалися виключно у рамках $\mathrm{OOH}$, за винятком участі країни у британській окупаційній зоні у Німеччині після завершення Другої світової війни. 31991 р. по 2017 р. майже 70 тис. данців взяли участь у міжнародних військових операціях, у той час як у період холодної війни ця цифра була удвічі менша -34 тис. осіб ${ }^{4}$.

Істотних змін зазнала також інституційна афіляція. 31991 р. по 2017 р. 33 з 68-и операцій відбулось під егідою ООН, а 21-a - у рамках НАТО, тоді як 10 було здійснено у рамках тимчасових коаліцій. Крім того, кожного десятиліття після завершення холодної війни відбувалось поступове скорочення участі в операціях ООН.

Зміна інституційної афіляції свідчила також про еволюцію завдань військових операцій, участь у яких брала Данія. Якщо у період холодної війни йшлося про миротворчі місії з мандатом $\mathrm{OOH}$, то у постбіполярний період - про застосування військових засобів з метою забезпечити мир чи стабілізувати ситуацію, часто без формальної згоди на це з боку усього міжнародного співтовариства.

Слід зауважити, що зростання військової активності Данії не супроводжувалось збільшенням витрат на неї. Якщо у роки холодної війни 2-3\% ВВП країни скеровувалися на оборону, то у постбіполярний період спостерігалося скорочення обсягів фінансування до рівня 1-2\%. Зокрема, 32013 р. по 2017 р. йшлося про 1,1-1,2\% ВВП . Нова оборонна угода на 2018-2023 рр. передбачає зростання фінансування військових потреб до 1,5\% ВВП, що все одно $є$ меншим показником, ніж 2\%, визначені зобов'язаннями по НАТО 6 .

Утім, було б хибою розглядати зовнішню політику Данії лише крізь призму атлантизму. У цієї країни є значні європейські амбіції, хоча й істотно обмежені. Найголовнішою перешкодою $є$ юридично закріплена добровільна неучасть в оборонній політиці ЄС. Наслідки цього рішення мають не лише символічне, а й практичне значення: Данія не може брати участі у військових інституціях ЄС. Це особливо помітно, коли йдеться про операції цивільно-військового характеру. Зокрема, вона не могла брати участі у таких місіях $6 C$ як EUFOR Althea у Боснії та Герцеговині чи EU NAVFOR Atalanta біля берегів Сомалі ${ }^{7}$.

\footnotetext{
${ }^{1}$ Mouritzen, H. (2007). Denmark's Super Atlanticism. Journal of Transatlantic Studies, 5 (2), 155-167.

${ }^{2}$ Ringsmose, J. Rynning, S. (2008). The Impeccable Ally? Denmark, NATO, and the Uncertain Future of Top Tier Membership. in N. Hvidt and H. Mouritzen (eds), Danish Foreign Policy Yearbook 2008. Copenhagen: Danish Institute for International Studies, 55-84.

${ }^{3}$ Henriksen, A., Ringsmose, J. (2011). Hvad fik Danmark ud af det? Irak, Afghanistan og forholdet til Washington. DIIS Report 14. Copenhagen: DIIS.

${ }^{4}$ Mariager, R. (2018). Denmark at War Patterns and Developments in Denmark's Military Engagement. AMS

$<$ http://ams.hi.is/wp-content/uploads/2018/06/Denmark-at-War-Patterns-and-Developments-in-Denmark's-MilitaryEngagement.pdf $>$. (2018, July, 12).

5 Там само.

6 Там само.

${ }^{7}$ Rynning, S. (2013). Denmark. in H. Biehl, B. Giegerich\&A. Jonas (eds). Strategic Cultures in Europe. Security and Defence Policies Across the Continent. Wiesbaden: Springer Fachmedien, 91.
} 
Пояснити підхід Данії до СС та НАТО можна крізь призму розподілу праці. Якщо у випадку НАТО, країна підтримує усі ініціативи, пов'язані з жорсткою безпекою, то у випадку СС ій йдеться про м'яку безпеку. При цьому, у Данії не підтримують концепцію стратегічної автономії ЄС, яка могла б підважити позицію Північноатлантичного альянсу. Водночас, королівство неприхильно ставиться до виконання у рамках НАТО завдань гуманітарного характеру, оскільки це може розмити спроможність альянсу до забезпечення військових гарантій.

Цей особливий тип прагматизму Данії простежується в операціях за її участю. Наприклад, коли данці брали участь у військовій повітряній операції НАТО у Лівії, вони одночасно активно підтримували ідею місії ЄС, яка спрямовувалася би на стабілізацію та постконфліктну відбудову цієї країни. Коли Данія брала участь у військових операціях НАТО в Афганістані, вона активно підтримувала багатосторонню програму $\mathrm{EC}$ EUPOL щодо розбудови поліцейських сил у цій країні. Подібну позицію Данія зайняла і у Косово. Водночас, треба згадати про розгортання данських й французьких військових в Албанії у 1997 р. у рамках місії ALBA, яку ініціювала та очолила Італія. Це єдина військова операція за участю Данії, яка не відбувалася ані під егідою НАТО, ані під керівництвом США. Оскільки реалізація вказаної ініціативи не суперечила інтересам НАТО та, зокрема, США, данці змогли взяти у ній участь з метою повернути стабільність у цю балканську країну ${ }^{1}$.

Розвиток данського мілітарного активізму позначався й продовжує здійснювати вплив на позицію та участь Данії у північноєвропейській співпраці. Незважаючи на те, що данці були досить ініціативними на етапі iї становлення, у пост-біполярний період їхня позиція не вирізнялась надмірною активністю. Королівство стримано ставилося до оборонної співпраці - не лише через власне членство в НАТО, а й з огляду на потреби військово-технічного характеру, відмінні від інших країн північної Свропи. Сьогодні Данія $\epsilon$ частиною НОРДЕФКО, проте не бере участі у Північноєвропейській бойовій групі, що діє у рамках ЄБОП.

Висновки. Активне застосування малими державами військової сили у зовнішній політиці $\epsilon$, радше, новим явищем. Данський мілітарний активізм поступово набув наступального характеру в площині забезпечення національних інтересів країни й відстоювання ліберально-демократичних цінностей. Така зовнішньополітична поведінка Данії не узгоджувалася 3 традиційним північноєвропейським підходом до питань безпеки, який вирізнявся миротворчістю, наданням допомоги чи використанням дипломатичних інструментів на випадок кризових ситуацій. Тим не менше, активне використання військової сили надійно утвердилося як один із ключових інструментів зовнішньої політики Данії.

Відмовляючись від участі в оборонному вимірі $€ \mathrm{C}$, Данія акцентує увагу на $Є С$ як форумі економічної співпраці. Це пов'язане з тим, що оновлена НАТО є ключовим майданчиком для Данії у безпековій сфері. Щоб ефективно брати участь у Північноатлантичному альянсі, Данія швидко адаптувалась до його безпекових підходів і вчинила міжнародний кризовий менеджмент ключовим елементом своєї безпекової політики.

\section{References:}

1. Gates, R. (2011). Text of Speech by Robert Gates on the Future of NATO. Atlanticcouncil $<$ https://www.atlanticcouncil.org/blogs/natosource/text-of-speech-by-robert-gates-on-the-future-of-nato/> . (2020, May, 12). [in English]

2. Hækkerup, H. (2002) På Skansen [At Skansen]. Denmark: Lindhardt and Ringhof. [in Danish].

3. Henriksen, A., Ringsmose, J. (2011). Hvad fik Danmark ud af det? Irak, Afghanistan og forholdet til Washington. [What did Denmark get out of it? Iraq, Afghanistan and relations with Washington] DIIS Report 14. Copenhagen: DIIS. [in Danish].

4. Heurlin, B. (1996). Denmark: a new activism in foreign and security policy. in Ch. Hill (Ed.), The Actors in Europe's Foreign Policy. London: Routledge. [in English].

5. Heurlin, B. (2004). Riget, magten og militceret. Dansk forsvars- og sikkerhedspolitik under forsvarskommissionerne of 1988 og af 1997 [The Realm, the Power, and the Armed Forces: Danish Defence and Security Policy during the 1988 and 1997 Defence Commissions]. Aarhus: Aarhus Universitetsforlag, 254-261. [in Danish].

6. Jakobsen, P. V., Ringsmose, J. (2014). In Denmark, Afghanistan is Worth Dying for: How Public Support for the War was Maintained in the Face of Mounting Casualties and Elusive Success. Cooperation and Conflict, 50, 2, 211-227. DOI: https://doi.org/10.1177/0010836714545688. [in English].

\footnotetext{
${ }^{1}$ Там само, 92.
} 
7. Kristensen, K. S., Larsen, K. K. (2017). Denmark's Fight Against Irrelevance, or the Alliance Politics of 'Punching Above Your Weight' in M. Wesley (Ed.), Global Allies. Comparing US Alliances in the 21st Century. Canberra: ANU Press, 59-70. [in English]

8. Mariager, R. (2018). Denmark at War Patterns and Developments in Denmark's Military Engagement. AMS $<$ http://ams.hi.is/wp-content/uploads/2018/06/Denmark-at-War-Patterns-and-Developments-in-Denmark'sMilitary-Engagement.pdf $>$. (2020, July, 12). [in English].

9. Moller, K. J., Jakobsen, P. V. (2012). Good News: Libya and the Danish way of War. in N. Hvidt and H. Mouritzen (eds), Danish Foreign Policy Yearbook 2012. Copenhagen: Danish Institute for International Studies, 106-130. [in English].

10. Mouritzen, H. (2006). Atlantic reform. A Euro-atlantic and a Danish perspective. Danish Institute for International Studies REPORT, 3. [in English]

11. Mouritzen, H. (2007). Denmark's Super Atlanticism. Journal of Transatlantic Studies, 5 (2), 155-167. [in English].

12. Mueller, K. P. (2015). Precision and Purpose: Airpower in the Libyan Civil War. Santa Monica: RAND Corp. [in English].

13. Pedersen, R. (2012). Danish foreign policy activism: Differences in kind or degree? Cooperation and Conflict, 47 (3), 331-349. [in English].

14. Petersen, N. (2006). Efter Muhammed: Handlerummet for den borgerlige udenrigspolitik. [After Muhammad: The Chamber of Commerce for Civil Foreign Policy]. Militcert Tidsskrift, 135 (2), 149-185. [in Danish].

15. Petersen, N. (2006). Europæisk Og Globalt engagement 1973-2006, Dansk Udenrigspolitiks Historie [European and Global Commitment 1973-2006, History of Danish Foreign Policy]. Bind 6. København: Gyldendal. [in Danish].

16. Petersson, M., Saxi, H. (2013). Shifted Roles: Explaining Danish and Norwegian Alliance Strategy 1949-2009. Journal of Strategic Studies, 36 (6), 761-788. [in English].

17. Rasmussen, A. F. (2003). Address by Prime Minister of Denmark Anders Fogh Rasmussen. The Woodrow Wilson Center, Washington, May 9. <http://www.stm.dk/ p 7430.html > (2016, August, 23). [in English]

18. Rasmussen, A. F. (2003). Visioner for Danmarks aktive Europapolitik. Statsminister Anders Fogh Rasmussens tale på Københavns Universitet den 23 September 2003 [Visions for Denmark's active European policy. Prime Minister Anders Fogh Rasmussen's speech at the University of Copenhagen on 23 September 2003]. STM $<\mathrm{http} / / /$ www.stm.dk/ p 7451.html> (2016, October, 10). [in Danish].

19. Ringsmose, J. Rynning, S. (2008). The Impeccable Ally? Denmark, NATO, and the Uncertain Future of Top Tier Membership. in N. Hvidt and H. Mouritzen (eds), Danish Foreign Policy Yearbook 2008. Copenhagen: Danish Institute for International Studies, 55-84. [in English].

20. Ringsmose, J., Jakobsen, P. (2015). Size and reputation - why the USA has valued its 'special relationships' with Denmark and the UK differently since 9/11? Journal of Transatlantic Studies, 13 (2), 135-153. [in English].

21. Rynning, S. (2003). Denmark as a strategic actor? Danish Security Policy after 11 September. in P. Carlsen and H. Mouritzen (eds), Danish Foreign Policy Yearbook 2003. Copenhagen: DIIS, 23-46. [in English].

22. Rynning, S. (2013). Denmark. in H. Biehl, B. Giegerich\&A. Jonas (eds). Strategic Cultures in Europe. Security and Defence Policies Across the Continent. Wiesbaden: Springer Fachmedien, 85-98. [in English].

23. Rynning, S., Ringsmose, J. (2008). The impeccable ally? Denmark, NATO, and the uncertain future of top tier membership. Danish Foreign Policy Yearbook 2008. Copenhagen: Danish Institute for International Studies, 55-84. [in English].

24. Szymański, P. (2018). Overstretched? Denmark's security policy and armed forces in light of the new Defence Agreement. OSW Commentary, 266. Centre for Eastern Studies $<$ https://www.academia.edu/36561702/ Piotr_Szyma\%C5\%84ski_Overstretched_Denmark_s_security_policy_and_armed_forces_in_light_of_the_new_ Defence Agreement OSW Commentary No 2662004 2018> (2019, May, 05). [in English].

25. Vedby, $\bar{M}$. (2011). Rasmussen, Den Gode Krig [Rasmussen, The Good War]. Copenhagen: Gyldendal. [in Danish]

26. Wivel, A. (2013). From Peacemaker to Warmonger? - Explaining Denmark's Great Power Politics. Swiss Political Science Review, 19 (3), 298-321. <https://onlinelibrary.wiley.com/doi/pdf/10.1111/spsr.12043> (2020, January, 17). [in English]. 